\title{
Strategic Policy for The Development of Electronic Judiciary in Indonesia During the Pandemic Period
}

\author{
Zulfia Hanum Alfi Syahr ${ }^{1}$, Muhamad Zaky Albana ${ }^{2}$, Tumbur Palti D. Hutapea ${ }^{3}$, Muh. \\ Ridha Hakim ${ }^{4}$ \\ \{qvia.alfisyahr@gmail.com¹, zakyalbana@gmail.com², tumburpalti79@gmail.com³, \\ id.mrhakim@gmail.com ${ }^{4}$ \}
}

Judiciary and Law Research and Development Center of Supreme Court of Republic of Indonesia, Jalan Jend. Ahmad Yani Kav. 58 bypass Cempaka Putih Jakarta Pusat ${ }^{1234}$

\begin{abstract}
The Electronic judiciary is a policy issued by e-court launching. This was to address global challenges as well as to realize the acceleration of case management. During the pandemic, litigation becomes hampered because it has to reduce physical contact in implementing health protocols. Therefore, the problems of case management that were previously done offline should begin to be diverted by optimizing the function of the e-court. Thus, the implementation of technology information is very important to ensure the court running process. The development of electronic judiciary is carried out by comparing with several countries to become evaluation and reference material. The goal is to make the electronic judiciary more accessible and easier to use by the public. The method used is a qualitative approach with policy conceptual comparison. The result is that the e-court must be able to facilitate up to the administrative process, the trial, until the verdict.
\end{abstract}

Keywords: case management; e-court; the pandemic; the electronic judiciary

\section{Introduction}

The concept of the electronic judiciary in Indonesia was initiated in 2014 with the implementation of the Case Tracking Information System (CTS) in all courts. The CTS application is a first step for the Supreme Court in starting the transition process from conventional to electronic in terms of filing case documents. The background of the application of technology in the judiciary is several problems in case administration in the court, including there are: 1) slow handling of cases; 2) scattered administrative responsibility for handling cases and; 3) recording the case handling process is not based on IT[1]. Seeing this problem, the court must start implementing IT to simplify and speed up the case management process. The application of IT is supported by the existence of a court digitization policy that continues to develop until the actual realization of electronic justice in Indonesia.

The development of information and technology has begun to be applied to the judicial process to realize a faster, simpler and, lower-cost case management that is integrated into the electronic judiciary system [2]. The real form of the electronic judiciary has started in 2018 with the launch of an e-court application by the Supreme Court. The application of the e-court is based on the Regulation of the Supreme Court of the Republic of Indonesia Number 3 of 
2018 about the Administration of Litigation in Courts Electronically and based on the principles of simple, fast and, low cost in the administration of justice in Indonesia[3]. The birth of e-court as a form of electronic justice in Indonesia continues to develop until 2019 elitigation with more complete features was launched. The emergence of e-litigation is based on the Regulation of the Supreme Court of the Republic of Indonesia Number 1 of 2019 about The Administration of Cases and Trials in Courts electronically. The difference between these two applications is that e-court focuses on case administration electronically, whereas elitigation features not only case administration but also electronic court proceedings.

The electronic judiciary emerged with the aim of providing a fast judicial process to the public based on the principles of justice, legal certainty, and benefit [3]. The use of technology in court is developed by taking into account the following matters: a) providing direct support to all court human resources in carrying out administrative functions; b) provide support for judicial management with a workflow management system; and c) provide support for interaction between the court and the parties by utilizing a network system. The role of technology is expected to increase the efficiency and effectiveness of case handling at the Supreme Court so that there is no more unresolved case accumulation.

Especially during the current pandemic, where court services must avoid physical contact and apply health protocols. The application of technology through e-court is very appropriate as a solution in court litigation during a pandemic. In addition to e-court, it can help reduce the build-up of cases, it can also be an alternative service to prevent the spread of the Covid-19 outbreak. The Supreme Court's policy on suggestions for processing in court online is a form of safety protection for judicial officials, justice seekers and court users (defendants, public prosecutors), advocates, witnesses, and court visitors) [4]. After the e-court, the Supreme Court began to develop another system in 2021, namely the E-Ris (Electronic Research and Information System) as a tool to assist judges in finding information and references to relevant decisions in deciding cases.

Several previous research results state that technology is currently a necessity for urban society and is a fundamental requirement of public services in government institutions to increase work effectiveness and efficiency [5]. Increasing the effectiveness and efficiency of public services today is evidence of the benefits of using technology in the application of egovernment in every government agency in various forms of application. Besides, the benefits of technological advances as part of globalization are that the government can provide more open services in providing access to information to the public [6].

Thus, courts as government agencies that provide services to the public must continue to innovate by taking advantage of technological advances to support the ease and speed of completing work. In this paper, we will discuss the development of electronic justice in Indonesia as an innovation in the judicial process to be compared with several other countries that have implemented it earlier. Then it will examine what more strategic aspects can still be developed and applied in Indonesian electronic justice.

Other countries' electronic courts that will be reviewed on appeal with e-court in Indonesia include the Public Access to Court Electronic Record (PACER) in the U.S., eSyariah in Malaysia and e-litigation in Singapore. Public Access to Court Electronic Record (PACER) was chosen as one of the comparisons because in America it has long been pioneering and implementing electronic justice in its country, besides that the e-court system in Indonesia has also more or less adopted from PACER. Then e-Syariah and e-litigation were chosen as a comparison of the development of the electronic judiciary in the closest neighbouring countries to Indonesia. 
It is hoped that the appeals study of electronic justice policies from three other countries can become a recommendation in the development of e-court in Indonesia so that it is more accessible, and the menus can accommodate the needs of justice seekers in court proceedings. It is hoped that the e-court will be able to answer the challenges of today's global development to become a modern justice system.

\section{Research Methods}

The research method used is qualitative research with a comparative approach to policy concepts applied in Indonesia with several other countries. The aim is to obtain data on the similarities and differences in the application of the electronic judiciary in Indonesia with several other countries. Data collection techniques are carried out by literature study through the collection of references and legal foundations related to the use of technology in law and justice with the application of the electronic judiciary in Indonesia.

The data obtained were analysed using the comparative method, namely looking for comparisons in terms of similarities and differences between the application of the electronic judiciary in Indonesia and several other countries. This comparative analysis is supported by a literature review of literature references as well as policies and regulations related to the study topic. The aim is to find strategic factors from the application of the electronic judiciary in several countries to be used as evaluation material and input for the application of the electronic judiciary in Indonesia.

\section{Results and Discussion}

\subsection{E-court in Indonesia}

E-court is an application that is integrated with the SIPP that can be used for several services, namely: 1) processing electronic registration (e-filling), 2) payment (e-payment) and estimated case fees (e-SKUM), 3) summons electronic trial (e-summon), 4) e-litigation. The difference between e-litigation and e-court is that e-court is more about transitioning case administration from manual to digital, whereas e-litigation is more of a court process based on network data[2]. Trial processes that can be facilitated in e-litigation include 1) trial schedules; 2) document answers, copies, copies to conclusions and written evidence can be sent electronically; 3) examination of witnesses and experts can be carried out by teleconference; 4) reading of the decision electronically without the participation of the parties and; 5) a copy of the decision sent electronically which has the same legal force as the physical copy. Thus, justice seekers no longer need to be present in the courtroom and are more cost-efficient because there is no more court summons. In the future, the e-court needs to be developed so that it can accommodate the proving process.

The implementation of e-court in all areas of the judiciary in Indonesia provides the advantage that the settlement of cases can be carried out more quickly. Other benefits of implementing e-court include: 1) the judiciary can run more simply and quickly; 2) can reduce the cost of the judicial process because it can be accessed online; 3) facilitate officers in managing case administration; 4) increase public trust in the court[7]. The change that has emerged since the implementation of the e-court in 2018 is that case arrears have decreased significantly from the year before the e-court was established. Table 1 below shows a decrease 
in case arrears from 2017 to 2019 . The change that has emerged since the implementation of the e-court in 2018 is that case arrears have decreased significantly from the year before the ecourt was established. Table 1 below shows a decrease in case arrears from 2017 to 2019.

Table 1. The Decreasing Case after the implementation of E-court

\begin{tabular}{cc}
\hline Year & $\begin{array}{c}\text { The Amount of } \\
\text { Arrears }\end{array}$ \\
\hline 2017 & 1388 \\
2018 & 906 \\
2019 & 217 \\
\hline
\end{tabular}

Source: Annual Report Supreme Court of Republic of Indonesia

In Table 1 above, it can be seen that since the implementation of e-court in 2018, case arrears have decreased quite a lot. From 2017 to 2018, the arrears in cases decreased by 482 cases, then in 2018 to 2019 after the implementation of the e-court, the arrears of cases decreased by 689 cases. From these data, it can be seen that within a year the use of e-court has shown a decrease in case arrears more than before the existence of e-court. Thus, efforts to reduce the number of case arrears can be supported by continuing to develop and maximize the function of the e-court to accommodate the entire process of the case and trial administration.

\subsection{Public Acces to Court Electronic Record (PACER) in U.S.}

The electronic judiciary in America began with the development of prototype case management or electronic case files (CM / ECF) in 1995 which were used for case management and registration[8]. Then in 1998 it became known as the "Courtroom21" program until 2005, it continued to develop under the name Public Access to Court Electronic Record (PACER). This program consists of virtual examinations, virtual law firms, payment of traffic fines online, remote testimony, remote forensic expert testimony, and electronic presentation of evidence[9]. The PACER system is a way of increasing public access to court information, which usually requires going to the local courthouse. Based on data on the official website PACER has provided the public with instant access to more than one billion documents filed in more than 200 federal courts as well as nearly all documents submitted by judges or parties in any case.

Public Access to Court Electronic Records (PACER) is a service of the federal judiciary whose mission is to provide the public with the widest possible access to court records and to promote a greater public understanding of the court system. PACER users include court staff; members, municipal, state, and federal employees; news media; and the general public. PACER offers easy electronic access to federal court records, such as the docket which is a record containing case information (case number, names of parties, etc.), proceedings and documents submitted, opinions, search for case-related information, information about the status of cases, court hearing audio files[10]. Besides, another use is that most papers use PACER data which should facilitate academic and policy research on important issues.

The success of implementing PACER can be seen in several aspects including the level of adaptation of each court, the legal community, and society, the volume of electronic files entered and generated by the court, the level of sustainability, validity, and independence of services, efficiency and effectiveness of officer services and improvement of the quality of the judiciary. as a whole[8]. Thus, seeing the development and advantages of the PACER application described above, Indonesia needs to emulate the features in PACER so that it can be implemented in e-court so that it has a more complete service menu. 


\subsection{E-syariah in Malaysia}

E-Syariah is one of the e-government projects developed in Malaysia. The implementation of IT in the judicial process in Malaysia is motivated by the length of the case management process, from registration to delayed case disposition in sharia courts which causes a buildup of cases every year[11]. E-Syariah began to be implemented in 2002 as a solution to improve the quality and efficiency of public services by utilizing IT[11]. The application has various features including the sharia court case management system, sharia lawyers registration system, e-portal, library management system, and office automation system, Audio Text Record (E-Talk), online living payments (E-Nafkah), online inheritance calculation (E-Faraidh)[12].

It is a nationwide Islamic Judicial Management System that enables syariah judges, syariah lawyers, registrars, court administrators as well as the public to enhance the internal administration and management of judicial processes at the court offices to ultimately realize good governance in the delivery of judicial services. This E-Syariah system encompasses the entire spectrum of Syariah court operations whereby it comprehensively addresses all issues related to the administration and management of Syariah court offices. E-Syariah is currently implemented at 111 Syariah court offices and operated by approximately over 600 syariah personnel including judges, lawyers, court administrators, and court users. The system provides a case management structure that integrates the processes related to the management and administration of cases for the Syariah Court Offices[13].

E-Syariah initiative has made attempts to streamline work processes in Syariah courts. It has categorized cases for example divorce, child custody, inheritance, and criminal offenses. Consequently, each case is treated uniquely and there is no overlap. At the same time, court record templates have been standardized and brought down from 104-40 gazetted forms only[12]. Over the years, the states' Syari'ah courts have introduced electronic innovations that aim to have a well-equipped system to store and analyze data so that a service, which is faster, more accurate, and of better quality, can be delivered to the court clients. Some of the innovations are $e$-Tray' and ' $i$-Post' in The Syari'ah Judiciary Department of Terengganu, eSyariah Instant Access Procedure (e-Siap) in Penang Syari'ah Judiciary Department, and $E$ Perintah to check the status of completion of the court orders and when they are ready to be collected in The Syari'ah Court of Melaka[14].

\subsection{E-litigation in Singapore}

The e-litigation application has been launched in 2013, which is a development of the Electronic Filling Service (EFS) system launched by Singapore on March 1, 2000. The main services of e-litigation include: 1) electronic filling service; 2) electronic extract service; 3) electronic service of document service, and 4) electronic information service[15]. The elitigation application also has service coverage for electronic document recording, Case Information Repository, case document submission between law firms (e-service), notification and notification of cases, case schedule information, financial transaction reports cases, court answers, and notifications, as well as case finding applications.

In this application, notification and court summons are no longer carried out with summoning letter but in the form of Short Message Service (SMS) notifications and e-mails. E-litigation has also been supported by a national citizen authentication system called SingPAS (a kind of Single Identity Number), which allows authentication of system user identities without attending and taking oaths[12]. 
The e-litigation system in Singapore is designed based on 4 principles, there are: 1) making information smarter; 2) building a case management system holistically / integrally; 3 ) consolidating the different systems to streamline case management systems, and 4) improve accessibility for all users[11]. Some of the challenges faced in implementing e-Litigation include: first, related to the large budget required to make the program run smoothly. The second problem is how to provide a large number of electronic forms for the case process. These forms must be available because the public needs them to litigate electronically. The third thing that is of main concern are security and authentication issue[11].

Although there are several challenges in implementing e-litigation, one year after the implementation of e-litigation, the number of criminal and civil cases that were submitted was 14,396 , then a total of 14,355 cases were able to be resolved within the same year[16]. Thus, it can be said that after the implementation of e-litigation, the success rate of resolving civil and criminal cases at the Supreme Court in Singapore reached 100\% in 2014. Based on these facts, it can be seen that the application of the electronic judiciary in Singapore has the impact of a faster process, which reduces the possibility of pile of unprocessed cases in court.

\section{Conclusion}

Based on comparisons of the electronic judiciary between Indonesia and the United States, Malaysia and Singapore, it can be seen that the e-court that has been developed since 2018 can provide integrated and solution handling services, especially during the Covid-19 pandemic in Indonesia. E-court development needs to be continued, especially in terms of developing service menus to facilitate the entire administrative and trial processes in court. Several services can be adopted by e-court by looking at the features of PACER, e-Syariah, and e-litigation, like the development of applications in the Android system so that a separate application is available on the mobile phone.

Then it is also necessary to integrate e-court with other systems required in the court such as the Case Tracking Information System (CTS) and e-Ris (Electronic Research and Information System) as implemented in e-Syariah. Of course, the development of e-court cannot be separated from the need to strengthen technology infrastructure and guarantee the security of confidentiality related to cases.

\section{Acknowledgements}

We would like to express our gratitude to Izarre Hanania Pratama, Adzkiya Azura Albana, Gisel, Geraldine, Adlan and Radiya for providing support on article preparation.

\section{References}

[1] S. J. Pratiwi, S. Steven, and A. D. P. Permatasari, "The Application of E-Court As An Effort to Modernize The Justice Administration in Indonesia: Challenges \& Problems," Indones. J. Advocacy Leg. Serv., vol. 2, no. 1, pp. 39-56, 2020.

[2] K. Santiadi, "Expanding Access To Justice Through E-Court In Indonesia," Prophet. Law Rev., vol. 1 , no. 1, 2019.

[3] A. Nursobah, "Pemanfaatan Teknologi Informasi Untuk Mendorong Percepatan Penyelesaian Perkara di Mahkamah Agung," J. Huk. dan Peradil., vol. 4, no. 2, pp. 323-334, 2015.

[4] W. Iswantoro, "Persidangan Pidana Secara Online Respon Cepat MA Hadapi Covid-19," Selisik, vol. 6 , no. $1,2020$. 
[5] R. A. Buchari, "Implementasi E-service Pada Organisasi Publik di Bidang Pelayanan Publik di Kelurahan Cibangkong Kecamatan Batununggal Kota Bandung," J. Sosiohumaniora, vol. 18, no. 3, pp. 235-239, 2016.

[6] H. Atthahara, "Inovasi Pelayanan Publik Berbasis E-Government: Studi Kasus Aplikasi Ogan Lopian Dinas Komunikasi Dan Informatika Di Kabupaten Purwakarta," J. Polit. Indones., vol. 3, no. 1, pp. 66-77, 2018.

[7] A. T. Kharlie and A. Cholil, "E-court And E-litigation: The New Face of Civil Court Practices in Indonesia," Int. J. Adv. Sci. Technol., vol. 29, no. 2, pp. 2206-2213, 2020.

[8] J. M. Greenwood and G. Bockweg, "Insights to Building a Succesful E-filing Case Management Service: U.S. Federal Court Experience," Int. J. Court Adm., vol. 4, no. 2, p. 2, 2012.

[9] F. I. Lederer, "Courtroom Technology: For Trial Lawyers, The Future Is Now," Crim. Justice, vol. 19, p. 14, 2004.

[10] A. C. Marco, Asrat, and A. A. Toole, "Patent Litigation Data from US District Court Electronic Records (1963-2015) (March 2017)," 2017-06, 2017.

[11] R. M. Ramli, "The Experience of Malaysian e-Government," in International Proceedings of Economics Development and Research, vol. 45, pp. 39-43.

[12] W. S. W. M. Saman and A. Haider, "E-Shariah in Malaysia: Technology Adoption Within Justice System," Transform. Gov. People, Process Policy, vol. 7, no. 2, pp. 256-276, 2013.

[13] M. R. Muhammad, "Managing Successful E-Government Implementation: Case of E-Syariah in Malaysia," University of Warwick, 2014.

[14] H. Haydar Ali Tajuddin, "Transforming and Globalising the Shari'ah Judiciary System of Malaysia," Islam. Law Malaysia, pp. 111-122, 2021.

[15] A. Cholil, "Belajar Dari Elitigation di Singapura," Majalah Peradilan Agama, vol. 14, Jakarta, pp. 43-45, 2018.

[16] CrimsonLogic, “Case Study: E-Litigation,” 2014. 